\title{
Cancers in Children Ages 8 to 12 Are Injury-Related
}

\author{
Kirsten H. Walen \\ CROMOS, Richmond, USA \\ Email: kwalencromos@gmail.com
}

Received 30 December 2014; accepted 5 February 2015; published 9 February 2015

Copyright (C) 2015 by author and Scientific Research Publishing Inc.

This work is licensed under the Creative Commons Attribution International License (CC BY). http://creativecommons.org/licenses/by/4.0/

c) (i) Open Access

\begin{abstract}
Cancers in young children in early growing age was a short PBS (KQED) report (11/21/2014), but without informational source, which prompted a Google search. Sports-associated injuries with medical healing treatments concluded that there were no association between these body traumas and cancer development. But there are other activities from young children, such as "dare-devil" skateboard and bicycling meter-high jumping with potential high energy falls, to serious brokenbone injuries. Falls of children are among the most common causes of US emergency response. The question is why bodily injury is associated with cancer-development? An answer to this question was exemplified by osteosarcoma in young children, which suggested that injury to growing points of bone and surrounding soft tissue cells would elicit a repair process (wound healing process) producing polyploidy with diplochromosomes. The non-mitotic reductive division of such 4-chromatid chromosomes has been shown in vitro to produce pathological cancer-like phenotypes, including gain of a proliferative advantage.
\end{abstract}

\section{Keywords}

Endomitosis, Endotetraploidization, Diplochromosomes, Reductive Division, Genomic Change, Proliferative Advantage, Wound Healing

\section{Introduction}

Over hundred years ago renowned pathologist von Hansemann concluded that cancers arose “- -from non-specific injury to a cell—”, not believed at that time and sparingly believed today [1].

Specifically, broken bones in childhood, a time when bones grow very rapidly from cell division (mitosis), the cancer cells were located inside and around ends of growing bones (osteo-sarcomas: thigh, arm, pelvic bone etc.). With von Hansemann in mind, the bone injuries trickle down to the cell level with an initial production of 
dead and sick, injured bone and soft tissue cells. Sick cells with genomic (DNA) damage must for survival-associated propagative ability repair the damage. Such cells from natural (dysfunctional telomeres) and induced sources (chemical, X-ray) showed changes to endo-tetraploidization (not regular doubling to 92 chromosomes) that could undergo a transient, mechanistic, genome reductive division (meiotic-like) to genome, altered progeny cells [2]-[5]. Inn passage-growth these altered cells expressed neoplastic-like phenotypes, including gain of a proliferative advantage (GPA) [3]. The notable biomarker for these divisions is 46 diplochromosomes, each chromosome with 4-chromatids, recently verified for "genome damaged" telomere-associated immortalization [6]-[8].

\section{Discussion}

The hypothesis here is that the repair process of the genomic damaged cells (sick cells) is linked to a wound healing system which can go wrong in a cancerous direction [9] [10]. Wound healing: replacement of damaged cells (Google: Tissue Repair and Wound Healing, 2009; W. H. Crawford) with scar formation require unscheduled cell proliferation, which is a tightly controlled system, but can involve genomic doubling to diplochromosomes [9], which would have probability of meiotic-like division to altered cells with neoplastic-like phenotypes (Walen, 2011) [11]. The aim is not to prove the hypothesis (require mouse models), but to draw attention to an irregular endotetraploid division that very likely is the route to a cancer-going wound healing process.

Genomic damaged cells from stalled replication forks or other sources (X-ray) become arrested, and respond by recruitment of multiple repair proteins in a focal arrangement $(\gamma \mathrm{H} 2 \mathrm{AX}$ foci) [12]. Repair can occur during resumed DNA synthesis (S-period) or in G2 (Gap) of the cell cycle. Prolonged G2 repair leads to increased tightness (cohesion) between the two chromatids by additional loading of cohesin genome-wide [13] [14]. This extra tightness is likely one reason for the formation of diplochromosomes (sister-pairs). Such G2-repairing cells skip mitosis (M) and goes directly to G1 with entry into S for an additional DNA-synthesis to 4-chromatid chromosomes [15] [16]. [To cleave the cohesion between the joined sister chromosomes (meiotic-like-1 division), activation of anaphase, APC-Cdc-20, lead to degradation of securin with activation of separase, producing two sister 2n/4C-nuclei, which followed by a second division produce near-2n/2C cells.] The cell cycle skip of $\mathrm{M}$ associated with prolonged G2 repair, is apparently caused by progressive degradation of mitotic required cyclin B-cdk1-kinase [16] [17]. From these latter authors, together with Zhang and co-workers [18] on endo-cycled giant nuclei, and their reduction division in ovarian cancer (to stem cells), it strongly appears, that anticancer therapy drugs that induce endocycling should be avoided [17]. There is also speculations of a timing constraint on the cell cycle [12], which with prolonged G2 arrest would activate "-cell cycle regulatory genes", thus, perhaps deregulating $M$ to $M$ kinetics [19]. [The cell cycle illustrated by a circle is divided into different timeperiods: G1 > S > G2 > M: with two daughter cell production, which can start a new round of: G1 > S > G2 > M; $\mathrm{G}=$ Gap, $\mathrm{S}=$ DNA-synthesis, $\mathrm{M}=$ mitosis.]

The lesson is that genomic damaged human cells (and not undamaged cells [14]) can produce tetraploidy with diplochromosomes, which notably occurs in the wound healing process with scar formation [9]. This 4-chromatid condition is the danger-situation for a potential beginning/initiation to genome changed cells, growing with neoplastic-like phenotypes [3] [20]—microscopy illustrated, “open access”. It stands to reason that normal mitosis, structured for 2-chromatid chromosomes, will have problems in spindle attachments dealing with 4-chromatid chromosomes. But, instead of expected chaotic mitoses, the diplochromosomal cells demonstrated activation of the transient, mechanistic, two-step meiotic-like division back to near-normal chromosome numbers (neardiploidy with 2-chromatid chromosomes). Asymmetric chromosomal distribution led von Hansemann to propose that it is the "-balance of chromosome numbers", "-in a cell that is the beginning of the cancerous growth" [1]. This conceptual view (aneuploidy) is not a foreign idea to present-day scientists [21] [22]: they see total, genomic physiology (a system with gene networking) as the operational machinery in cancer beginning and growth, and not, effects from single mutational events as especially, is promoted for initiation in the mutation theory [23]. A type of co-operation known as, antagonistic pliotropy, also occurs among neighboring cells and "cancer to be" cells [24].

The endo-derived near "diploid" daughter cells showed cancer-like growth-pathology (microsopy demonstrated) and, increased growth-rate over normal cells of origin. A cancerous process fundamentally require gain of a proliferative advantage [25], which has been linked to loss of tumor suppressor-genetics, as for example, mutated p53 gene (i.e., loss of heterozygosity $(\mathrm{LOH})$ ). This, latter aspect together with growth-attained muta- 
tional changes (in progression) has been found to involve further polyploid asymmetric cell cycling [26] [27], which can lead to "physiology changes" allowing "aggressive" cancer cells to spread to other parts of the body.

As mentioned above the present outlined cellular events for a potential cancerous process is not recognized among cancer-research scientists today. However, in similarity with other "awakenings" in life, the pendulum must swing out of its normal course before there is recognition that may lead to action. Such discrepancy is hopefully, here the claimed relationship between gross bodily injury and development of osteosarcoma in young children. From in vitro experimental data it is hypothesized that the cancerous process was a probability in a normal wound healing system. However, the present molecular, machine-based methodology (PCR, SNP-array, flow cytometry, CGH) in cancer investigations would have a hard time showing cellular early pre-neoplastic events without the help from mitotic studies. As pointed out by Gasgoigne and Taylor [17] western blotting and flow cytometry produce "indirect data" subject to interpretations. This shift to machine-based molecular studies has in essence eliminated recognition of tumorigenic-associated early events by abolishing mitotic studies [22]. The earlier, tumorigenic biomarkers can be detected, the more favorable therapy treatments can be expected [28].

Of note, in this case of osteosarcoma in young children the choice of cellular mechanism for cancer required GPA was endopolyploid, mechanistic reductive division and not telomere-dysfunction to immortalized proliferating cells, because the latter gain of GPA is hardly applicable to 8 - 12 years olds. It now remains to assess, if the initial skip of mitosis affected subsequent cell cycles with shorter time-periods. If so, gain of a proliferative advantage may be a result from shorter cell cycle times of repaired/mutant cells capable of original "normal" proliferation plus up/down regulated new genetic-based transcriptions. Support for this suggestion comes from: late inactivation of the "hallmark" tumor suppressor p53 gene, and that cell lines in general show reduced cycling times compared to cells of origin. For the present human endo-derived cells the cycling time from $\mathrm{M}$ to $\mathrm{M}$ was roughly estimated to be 14 to 16 hours compared to the fibroblasts with $20-22$ hours. And, as the originator of PtK-1 \& 2 cell lines [29] at a time when labeling with tritiated thymidine was popular, these cell lines cycled with 10 - 12 hours, considerably reduced from wild-type cells (unpubl.).

The present review points out that there is strong possibility in a wound healing process that G2 repairing cells have the capacity to activate a rather complex, orderly, non-mitotic division system with potential for a cancerous pathway. Thus, induction of meiotic-like division is a genetic response hidden in man's genome that very likely originated from evolutionary conserved, primitive unicellular divisions [30] [31]. Uhlmann [14] from considerations of prokaryotic (Bacteria) chromosomal segregation concluded in regard to cohesion between chromatids (normally established during S) that the function of ancestral cohesins were "-largely recapitulated in eukaryotes-". Furthermore, that "enrichment" of cohesin was a G2 repair-associated conserved, genomewide function, especially loaded at fragile sites and centromere regions. These conserved functions from relic genetics in man's genome, most likely are the causes for sister chromatids staying cohesed with result of diplochromosomes during mitotic slippage to a second S-period.

The frustrating problem today is that doubling of the human genome is generally interpreted to produce 92 chromosomes, which is the case in some spindle-poison experiments without genomic damage. This has led to assumed asymmetric divisions producing aneuploidy for a tumorigenic pathway [32] [33]. However, the aneuploid paradox [34] is that such originated aneuploidy is growth retarding, and most importantly, none of these types of experiments/ideas to aneuploidy has resulted in GPA, a feature, so far linked only to immortalization and endopolyploid derived cells. The shift to different levels of endopolyploidy with division capacity [35] is not caused by mutational events considering the observable, significant frequency of meiotic-like divisions and, it being a genetic program in man's genome. Several studies have shown transcriptional changes on the RNA level for normal and cancer cell gene-expression [18] [36], which speculatively, would be manifested by normal versus endo-derived proliferating cells. If true, it would be a far different "beginning" to "gain in fitness" (GPA) as suggested by the mutational theory: "—virtually all cancers result from the accumulated mutations in genes that increase the fitness of a tumor cell over that of the cells that surround it" [37]. In fact "short cell cycling times" may alter or add another dimension to the increased fitness proposal.

The suggested transcriptional changes can be helped by the newly discovered carcinogen-free induction-system for occurrence of genome damaged cells proceeding to somatic "meiosis" [38]. It is a nutritional-based system (glutamine deprivation of normal, human cells), which stops proliferation with the cells taking on a shrunken phenotype, and on the genome level stops all DNA replicating forks, evident from massive chromosome breakage in some recuperated cells, while other cells showed sister chromatid exchanges and meiotic-like divi- 
sions to proliferating para-diploid cells [3]. The urgency in active research into the consequences of transient endopolyploid reductive division is not only evident from the present case of bone cancer linked to genome damage with a cancerous pathway, but also from probability of occurrence among seniors (poor diets, insufficiency of amino acids) where the cancer-rate is the highest.

\section{Conclusion}

In conclusion from the facts of osteosarcoma occurrence in young children with broken bones, which must go through a wound healing process, it makes sense that a potential neoplastic process can be a wrong cellular route in the healing process. Wounds heal by unscheduled cell proliferation, inter-linked with repair of cells with genomic damage, which is the trigger for initiation of irregular endopolyploid cell division. Was von Hansemann right in his intuitive suggestion of "non-specific injury to a cell” in the origin of cancers? Avoidance of such injuries in the young children would be reduction in activities with chance of falling, which becomes a parent issue.

\section{References}

[1] Bignold, L.P., Coghlan, B.L.D. and Jersmann, H.P.A. (2007) David von Hansemann: Contributions to Oncology: Context, Comments and Translations. Birkhauser Verlag, Basel, 83, 108.

[2] Walen, K.H. (2012) Genome Reversion Process of Endopolyploidy Confers Chromosome Instability on the Descendent Diploid Cells. Cell Biology International, 36, 1-9. http://dx.doi.org/10.1042/CBI20110052

[3] Walen, K.H. (2013) Normal Human Cells Acquiring Proliferative Advantage to Hyperplasia-Like Growth Morphology: Aberrant Progeny Cells Associated with Endopolyploid and Haploid Divisions. Cancer and Clinical Oncology, 2, 1-15. http://dx.doi.org/10.5539/cco.v2n2p19

[4] Huna, A., Salmina, K., Jascenko, E., Duburs, G., Inashkina, I. and Erenpreisa, J. (2011) Self-Renewal Signaling in PreSenescent Tetraploid IMR90 Cells. Journal of Aging Research, 2011, Article ID: 103253. http://dx.doi.org/10.4061/2011/103253

[5] Shwarz-Finsterle, J., Scherthan, H., Huna, A., Gonzalez, P., Mueller, P., Schmitt, E., Erenpreisa, J. and Hausmann, M. (2013) Volume Increase and Spatial Shifts of Chromosome Territories in Nuclei of Radiation-Induced Polyploidizing Tumor Cells. Mutation Research/Genetic Toxicology and Environmental Mutagenesis, 756, 56-65. http://dx.doi.org/10.1016/j.mrgentox.2013.05.004

[6] Walen, K.H. (2006) Human Diploid Fibroblast Cells in Senescence: Cycling through Polyploidy to Mitotic Cells. In Vitro Cellular \& Developmental Biology. Animal, 42, 43-50.

[7] Walen, K.H. (2007) Bipolar Genome Reductional Division of Human Near-Senescent Polyploid Fibroblast Cells. Cancer Genetics and Cytogenetics, 173, 43-50. http://dx.doi.org/10.1016/j.cancergencyto.2006.09.013

[8] Davoli, T. and de Lange, T. (2011) The Causes and Consequences of Polyploidy in Normal Development and Cancer. Annual Review of Cell and Developmental Biology, 27, 585-610. http://dx.doi.org/10.1146/annurev-cellbio-092910-154234

[9] Ermis, A., Oberringer, M., Wirbel, R., Kochnick, M., Mutschler, W. and Hanselmann, R.G. (1998) Tetraploidization Is a Physiological Enhancer of Wound Healing. European Surgical Research, 30, 385-392. http://dx.doi.org/10.1159/000008603

[10] Eming, S.A., Krieg, T. and Davidson, J.M. (2007) Inflammation in Wound Repair: Molecular and Cellular Mechanisms. Journal of Investigative Dermatology, 127, 514-525. http://dx.doi.org/10.1038/sj.jid.5700701

[11] Walen, K.H. (2011) Normal Human Cell Conversion to 3-D Cancer-Like Growth: Genome Damage, Endopolyploidy, Senecence Escape, and Cell Polarity Change/Loss. Journal of Cancer Therapy, 2, 181-189. http://dx.doi.org/10.4236/jct.2011.22023

[12] Weinert, T. (2007) What a Cell Should Know (but May Not). Science, 315, 1374-1375. http://dx.doi.org/10.1126/science.1140759

[13] Unal, E., Heidinger-Pauli, J.M. and Koshland, D. (2007) DNA Double-Strand Breaks Trigger Genome-Wide Sister Chromatid Cohesion through Eco1 (Ctf7). Science, 317, 245-248. http://dx.doi.org/10.1126/science.1140637

[14] Uhlmann, F. (2009) A Matter of Choice: The Establishment of Sister Chromatid Cohesion. EMBO Reports, 10, 10951102. http://dx.doi.org/10.1038/embor.2009.207

[15] Ishida, R., Sato, M., Narita, T., Utsumi, K.R., Nishimoto, T., Morita, T., Nagata, H. and Andoh, T. (1994) Inhibition of DNA Topoisomerase II by ICRF-193 Induces Polyploidization by Uncoupling Chromosome Dynamics from Other Cell Cycle Events. Journal of Cell Biology, 126, 1341-1351. http://dx.doi.org/10.1083/jcb.126.6.1341

[16] Brito, D. and Rieder, C.L. (2006) Mitotic Checkpoint Slippage in Human Occurs via Cyclin B Destruction in the Pres- 
ence of an Active Checkpoint. Current Biology, 16, 1194-1200. http://dx.doi.org/10.1016/j.cub.2006.04.043

[17] Gasgoigne, K.E. and Taylor, S.S. (2008) Cancer Cells Display Profound Intra- and Interline Variation Following Prolonged Exposure to Antimitotic Drugs. Cancer Cell, 14, 111-122. http://dx.doi.org/10.1016/j.ccr.2008.07.002

[18] Zhang, S., Mercado-Uribe, I., Xing, Z., Sun, B., Kuang, J. and Liu, J. (2013) Generation of Cancer-Stem-Like Cells through the Formation of Polyploidy Giant Cancer Cells. Oncogene, 33, 116-128. http://dx.doi.org/10.1038/onc.2013.96

[19] Coshi, C.H. and Dick, F.A. (2012) Chromosome Instability and Deregulated Proliferation: An Unavoidable Duo. Cellular and Molecular Life Sciences, 69, 2009-2024. http://dx.doi.org/10.1007/s00018-011-0910-4

[20] Walen, K.H. (2014) Haploidization of Human Diploid Metaphase Cells: Is This Genome Reductive Mechanism Operational in Near-Haploid Leukemia? Journal of Cancer Therapy, 5, 101-114. http://dx.doi.org/10.4236/jct.2014.51013

[21] Huang, S., Ernberg, I. and Kauffman, S. (2009) Cancer Attractors: A Systems View of Tumors from a Gene Network Dynamics and Developmental Perspective. Seminars in Cell \& Developmental Biology, 20, 869-876. http://dx.doi.org/10.1016/j.semcdb.2009.07.003

[22] Heng, H.H., Bremer, S.W., Stevens, J.B., Horne, S.D., Liu, G., Abdallah, B.Y., Ye, K.J. and Ye, C.J. (2013) Chromosomal Instability (CIN): What It Is and Why It Is Crucial to Cancer Evolution. Cancer and Metastasis Reviews, 32, 325-340. http://dx.doi.org/10.1007/s10555-013-9427-7

[23] Vogelstein, B. and Kinzler, K.W. (1993) The Multistep Nature of Cancer. Trends in Genetics, 9, 138-141. http://dx.doi.org/10.1016/0168-9525(93)90209-Z

[24] Rodier, F. and Campisi, J. (2011) Four Faces of Cellular Senescence. Journal of Cell Biology, 192, 547-556. http://dx.doi.org/10.1083/jcb.201009094

[25] Hanahan, D. and Weinberg, R.A. (2011) Hallmarks of Cancer: The Next Generation. Cell, 144, 646-674. http://dx.doi.org/10.1016/j.cell.2011.02.013

[26] Mosieniak, G. and Sikora, E. (2010) Polyploidy: The Link between Senescence and Cancer. Current Pharmaceutical Design, 16, 734-740. http://dx.doi.org/10.2174/138161210790883714

[27] Steinbeck, R.G. (2004) Dysplasia in View of the Cell Cycle. European Journal of Histochemistry, 48, $203-211$.

[28] Collado, M. and Serrano, M. (2010) Senescence in Tumors: Evidence from Mice and Humans. Nature Reviews Cancer, 10, 51-57. http://dx.doi.org/10.1038/nrc2772

[29] Walen, K.H. and Brown, S.W. (1962) Chromosomes in a Marsupial (Potorous tridactylis) Tissue Culture. Nature, 194, 406. http://dx.doi.org/10.1038/194406a0

[30] Haig, D. (1993) Alternatives to Meiosis: The Unusual Genetics of Red Algae, Microsporidia and Others. Journal of Theoretical Biology, 163, 15-31. http://dx.doi.org/10.1006/jtbi.1993.1104

[31] Walen, K.H. (2014) Neoplastic-Like Cell Changes of Normal Fibroblast Cells Associated with Evolutionary Conserved Maternal and Paternal Genomic Autonomous Behavior (Gonomery). Journal of Cancer Therapy, 5, 860-877.

[32] Li, R., Sonik, A., Stindl, R., Rasnik, D. and Duesberg, P. (2000) Aneuploidy vs. Gene Mutation Hypothesis of Cancer: Recent Study Claims Mutation but Is Found to Support Aneuploidy. Proceedings of the National Academy of Sciences of the United States of America, 97, 3236-3241. http://dx.doi.org/10.1073/pnas.97.7.3236

[33] Storckova, Z. and Pellman, D. (2004) From Polyploidy to Aneuploidy, Genomic Instability and Cancer. Nature Reviews Molecular Cell Biology, 5, 45-54. http://dx.doi.org/10.1038/nrm1276

[34] Williams, B.R., Prabhu, V.R., Hunter, K.E., Glazier, C.M., Whittaker, C.A., Housman, D.E. and Amon, A. (2008) Aneuploidy Affects Proliferation and Spontaneous Immortalization in Mammalian Cells. Science, 322, 703-709.

[35] Erenpreisa, Je., Cragg, M.S., Anisimov, A.P. and Illidge, T.M. (2011) Tumor Cell Immortality and the Ploidy Number 32n? Is It a Developmental Checkpoint? Cell Cycle, 10, 1873-1874. http://dx.doi.org/10.4161/cc.10.11.15755

[36] Bar-Joseph, Z., Siegfried, Z., Brandeis, Z.B., Brors, B., Lu, Y., Eils, R., Dynlacht, B.D. and Simon, I. (2008) GenomeWide Transcriptional Analysis of the Human Cell Cycle Identifies Genes Differentially Regulated in Normal and Cancer Cells. Proceedings of the National Academy of Sciences of the United States of America, 105, 955-960. http://dx.doi.org/10.1073/pnas.0704723105

[37] Bozic, I., Antal, T., Ohtsuki, H., Carter, H., Kim, D., Chen, S., Karchin, R., Kinzler, K.W., Vogelstein, B. and Nowak, M.A. (2010) Accumulation of Driver and Passenger Mutations during Tumor Progression. Proceedings of the National Academy of Sciences of the United States of America, 107, 18545-18550. http://dx.doi.org/10.1073/pnas.1010978107

[38] Stern, C. (1958) The Nucleus and Somatic Cell Variation. Journal of Cellular and Comparative Physiology, 52, 1-34. http://dx.doi.org/10.1002/jcp.1030520404 
Scientific Research Publishing (SCIRP) is one of the largest Open Access journal publishers. It is currently publishing more than 200 open access, online, peer-reviewed journals covering a wide range of academic disciplines. SCIRP serves the worldwide academic communities and contributes to the progress and application of science with its publication.

Other selected journals from SCIRP are listed as below. Submit your manuscript to us via either submit@scirp.org or Online Submission Portal.
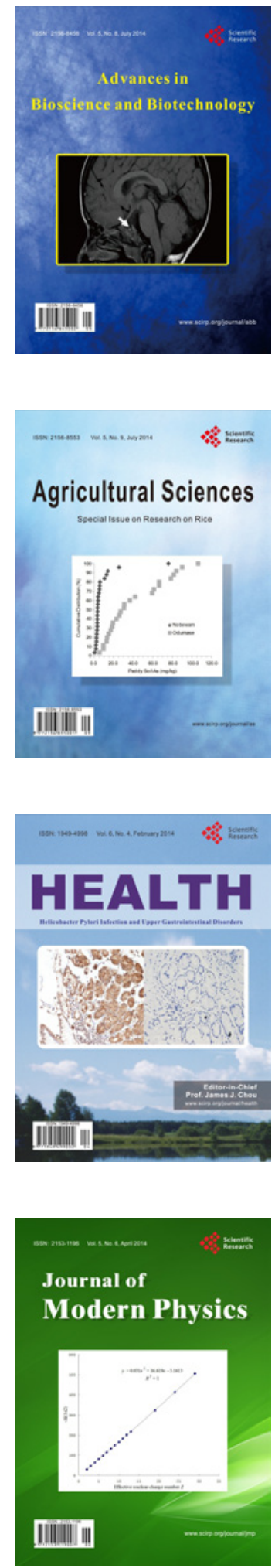
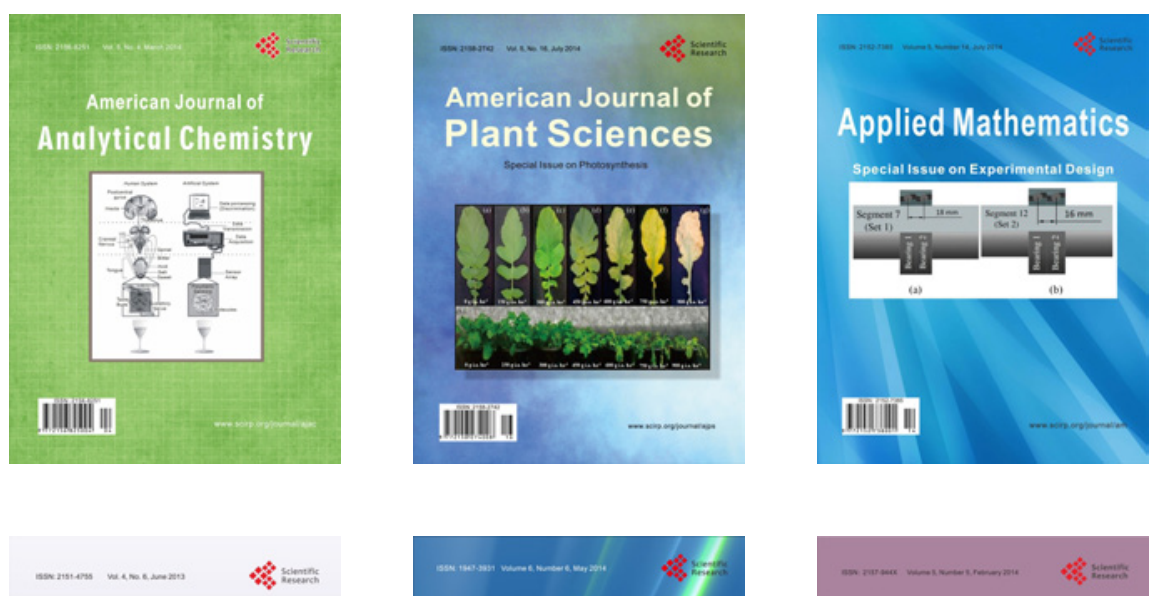

Creative Education
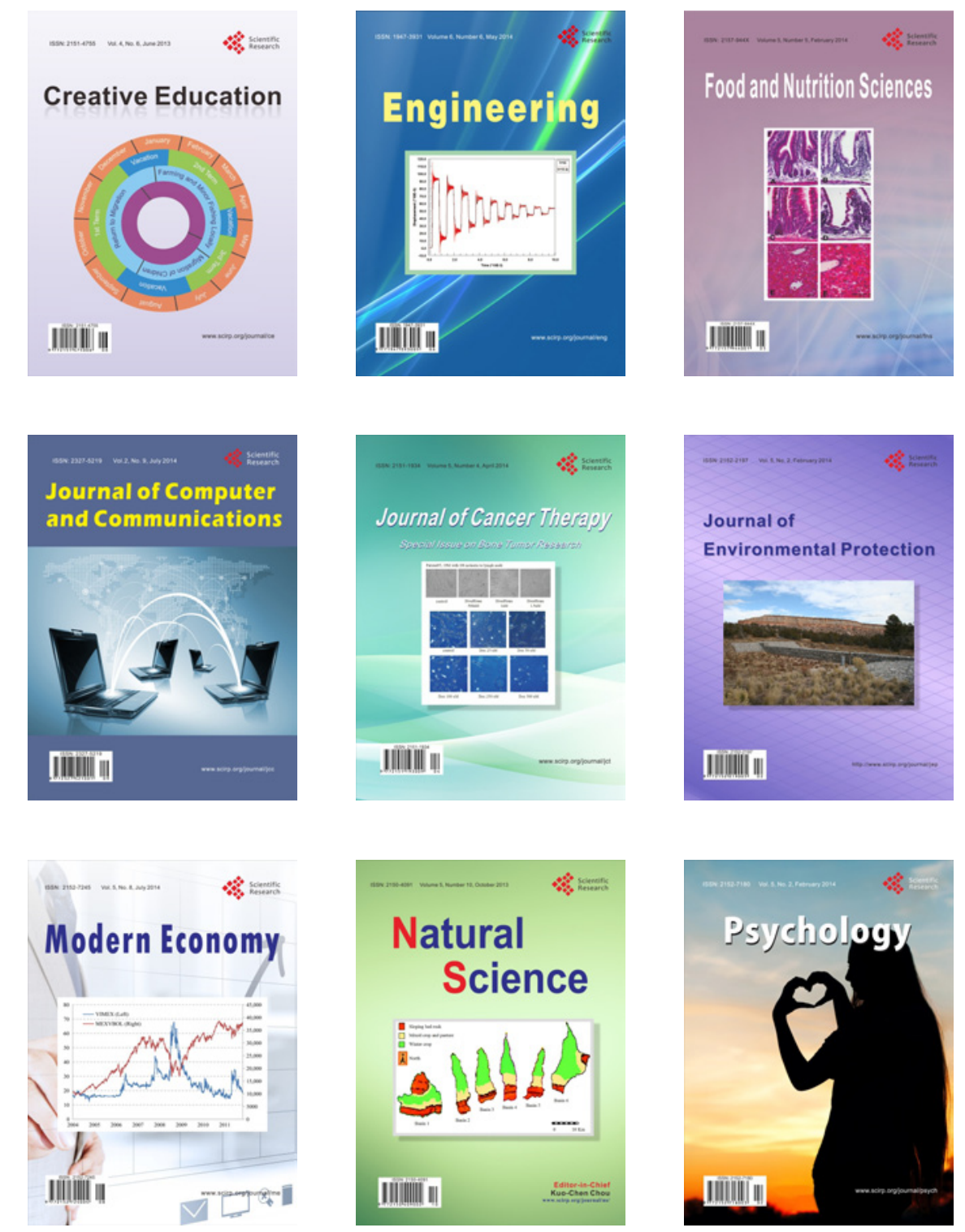